\title{
AN ANALYSIS OF FIGURATIVE LANGUAGE IN AVRIL LAVIGNE SONGS IN ALBUM AVRIL LAVIGNE.
}

\author{
Abdullah$^{1}$, Ugi Rahayu Rahmawati ${ }^{2}$ \\ STIBA - IEC Bekasi. \\ abdullahgraha@yahoo.com ${ }^{1}$, Ugi.victory@yahoo.co.id ${ }^{2}$
}

\begin{abstract}
This research aims to know and understanding the element of literature, especially in figurative language. The objectives of this research are (1). To identify some elements of figurative language are used by Avril Lavigne's songs lyric. (2). To show the general meaning and detail meaning of the songs containing the figurative language itself in understanding songs lyric. (3). To find out the most and the least used figurative language of the songs. The data source used is the album self-titled Avril Lavigne by Avril Lavigne. In that album the writer chooses five songs to analyzed such as, Here's to Never Growing Up, Bitchin' Summer, Give You, What You Like, Hello Kitty, and Sippin' on Sunshine. This research is descriptive qualitative research. It means that this research does not calculate the data and just gives description about figurative language that is contained in Avril Lavigne songs. It is done by using bold and underlining the songs lyric, classifying the figurative language and then giving the meaning. The result of this research is to discover some kinds of figurative language such as, Metaphor, Simile, Personification, Alliteration, Allusion, Hyperbole, Litotes, also Onomatopoeia.
\end{abstract}

Keywords : Literature, Figurative Language, Qualitative descriptive analysis.

\section{A. INTRODUCTION}

\section{Background}

Figurative language is language using figure of speech. According to Abrams, "Figurative language is a conspicuous departure from what users of a language apprehend as the standard meaning of words, or else the standard order to words, in order to achieve some special meaning or effect." It can be clear that figurative language is not common from the language that we use in daily. 
Figurative language cannot be separated with figure of speech. Commonly, we can find figure of speech in poem, novel, and song. In this research, the writer choose a song to describe the meaning of the song lyric itself using figurative language.

Song has an important impact of human beings. People use song as a tool to express their feeling, ideas, emotion, and also message for their life. Song it could become a critics of political also for charity activity. Then, the song can use to express the positive and negative message to the speaker's. Human used a song to show their emotions. They are connected with their situation. If the people are happy, sad, angry, and bored, they certainly use the song to calm down their thought and make it emotion and situation feel better.

Song is a short poem or other set of words set to music or meant to be sung. The singer uses song to show and to expose that the message from our daily. Song is usually followed by musical instrument. So, the song can make the hearer more interested in hearing it, such as in Avril Lavigne songs. The writer chooses Avril Lavigne songs because Avril Lavigne is a song writer and also a singer. She is from Canada, she was born on September 27, 1984. She is one of the best singers in the world. Many people know her songs. She has known her potency in music when she was two years old. She started in church singer and she made a band with her friends. Her talent in music has been admitted in many countries. Her beautiful song lyric that makes people interested to hear it.

Lyric is the words of a popular song. Lyric usually uses figurative language to make a deep and wonderful meaning. In this research, the writer focuses on figurative language of songs lyric. The writer intends to find some kinds of figurative language such as metaphor, simile, personification, apostrophe, alliteration, allusion, hyperbole, understatement (litotes), irony, paradox, metonymy, synecdoche, onomatopoeia. The writer hopes with this research, the reader will know clearly the purpose to analyze songs lyric. Therefore, this research is entitled 'An Analysis of Figurative Language in Avril Lavigne's Songs in Album Avril

\section{Lavigne’}

\section{Objective}


The objectives of this research are to find out the figurative language and the general meaning used in Avril Lavigne's Songs in Album Avril Lavigne'.

\section{Theoritical Framework}

\subsection{Definition of Figurative Language}

Cristina Caccia and Sam Glucksberg defines that "figurative language is no longer perceivied as merely an ornament added to everyday. It means figurative language not only used in literal meaning but also viewed as powerful communicative and conceptual tool in daily activity. Giora also claimed that "figurative language is literal language be viewed as governed by more general principle of salience, according to which salient meanings are processed first. So, it can be concluded that figurative language is ubiquitous in many forms of discourse, no more difficult to understand in context than literal language. The writer defined that figurative language as a tool to describe expression that usually expressed in figurative meaning or non literal meaning. Most people express their thought or feeling in indirectstatement. They prefer using non literal meaning. In addition, figurative language as the creative imagination of the writer or speakers can give the pleasure to the readers.

\subsection{Definition of Song}

Song is one of type in literature that can be used in literary term. It may be used to create a more relaxing and fun feeling in each situation. In that case, song can be more helpful to the speaker enjoying the song when they hear it. In Humberto Eco"s (1979) terms, songs are open text. In Receptive Methods in Music Therapy book, Bruscia (1998) stated songs express who are and how we feel, they bring us closer to others, they keep us company when we are alone. It means that song helps our feeling and sense to express our life stories. Grocke and Wigram also stated songs become popular when the lyrics speak of everyday situations that people experience, for example: relationships, identity, peace, drugs, and aggression. 


\subsection{Definition of Lyric}

Abrams says "lyric is any fairly short poem, consisting of the utterance by a single speaker, who expresses a state of mind or a process of perception, thought, and feeling." In the original greek, "lyric" signified a song rendered to the accompaniment of a lyre. Abrams added " in some usage, lyric still retains the sense of a poem written to be set to music ". It means that lyric is a set of words that make up a song. From those theories, lyric candemonstrate specific moods and emotions through words. Lyric can also be analyzed from an academic perspective. For example, some lyrics can be considered as a form of social commentary and deliver a positive and negative messages with respect to the sense of unity or lack of unity in music.

\subsection{Kinds of Figurative Language}

1) Metaphor

The word metaphor is derived from the greek word "Metaphoria", which meant "to carry". Metaphor is a comparison of two different phenomena which share some common point. ${ }^{11}$ It is that makes an implicit, implied, or hidden comparison between two things that are unrelated, but which share some common characteristic. In other words, a resemblance of two contradictory of different object is made based on a single or some common characteristics, ( https://iterarydevice.net/metaphor/on 27 July 2017 at 08.35 am.). John Searle has claimed that metaphors have a metaphorical meaning which can be explained in terms of the uttere"s, as contrasted with the literal, meaning. Mark Robson and Peter Stockwell says"using metaphor can be seen as a sort of mental mapping between two domains: a target (the new element that is being focused upon) and a source (which is being used to reconfigure our understanding of the target)" . They added "..in the most famous example from Shakespeare, "Juliet is the sun". Where the new target is "Juliet" is understood by reference to the familiar source "the sun". Kövecses also defined the conceptual metaphors consist of a source and target domain.

George Lakoff and Mark Johnson stated " Literal language, asumed to be mutually exclusive with metaphor, has been taken to be real stuff of philosophy, 
the domain where issues of meaning and truth arise and can be dealt with". So, when we say, "Richard is a lion", what we are doing is subtituting the expression a lion for brave. Those sentences called metaphor because Richard is not a lion. Lion is expressed the carachter of Richard. However, we can use this comparison to describe an association of a lion with that person.

Christopher gives another example, "Sally is a block of ice" is to attempt to get us to see her as a block ice. In this sentence, we must really "see" here, presumably, not simply as "visual perceive", but so as to include „visualise" and „think of" or „imagine" (but not „believe") “. According to that example, briefly, it can be said that metaphor is commonly useful in literary device. Using metaphor help the speaker to present unfamiliar ideas or situations and also help the readers can create their own creative ideas as a literary works. That is why there are many examples of metaphor can be found in literature.

\section{2) Simile}

Rashid Hussain stated " The word simile is derived from the Latin word "Simile” meaning „resemblance and likenesses", technically it means the comparison of two objects with some similarities ". Abrams also says in simile, a comparison between two distinctly different things is explicity indicated by the word"like" and "as". In addition, simile is fundamentally a figure of speech requiring overt reference to source and target entities, and an explicit construction connecting them (Gibbs, 1994:40). It can be concluded that simile is a figure of speech that makes a comparison, showing similarities between two different things with using a connectors.

An example of simile is given by Shawn Mendes in his song entitled Stitches, "Just like a moth drawn to a flame, Oh you lured me in, I couldn"t sense the pain, you bitter heart cold to the touch, Now I"m gonna reap what I sow, I"m left seeing ed on my own." In that lyic, Mendes compares between physical hurt and emotional pain. In addition, it inspires life-like quality in our daily talks and in the characters of fiction or poetry. Simile allows readers to relate the feelings of a writer to their personal experiences. The use of similes makes it easier for the readers to understand the subject matter of a literary text, which may have been otherwise too demanding to be comprehend. 


\section{3) Personification}

Abrams says another figure related to metaphor is personification, In the Greek term, prosopopeia, in which either an inanimate object or an abstract concept is spoken as though it were endowed with life or human attributes or feelings. When we say "the sky weeps", we are giving the sky the ability to cry, which is a human quality. Thus, we can say that the sky has been personified in the given sentence. Writers and poets rely on personification to bring inanimate things to life, so that their nature and actions are understood in a better way. In another example, from Romeo and Juliet, Act I, Scene II by William Shakespeare, "When well-appareled April on the hell of limping winter treads." In that scene, April is the name of month. It cannot put on a dress and winter does not limp. Shakespeare personifies the month of April and the winter season by giving them two distinct human qualities.

Personification is used to help the writer describe a condition in literary way. Through personification, the reader can be excited to express their condition more powerful and meaningful giving the human qualities related of inanimate objects to our own emotions. It can be concluded that personification is very helpful and useful device for an author for the literary works.

\section{4) Apostrophe}

In literature, apostrophe is a figure of speech in which animate or inanimate objects are adressed in the second person as thought present. It is important not to confuse the apostrophe which is a figure of speech and the apostrophe which is a punctuation mark (,). This is example for apostrophe using a punctuation mark, "The boy's bike is red" The word boy's using apostrophe "s" it belonging to boy. But, in literary term it is informal apostrophe. Apostrophe is an arrangement of words adressing a non - existent person or an abstract idea in such a way as if it were present and capable of understanding feelings, ( https://literarydevice.net/apostrophe/ on 01 August 2017 at 11.38 am.).

Other example from that site " an example of apostrophe is given by Mary Shelly in her novel Frankensteins, "Oh! Stars and clouds and winds, ye are all about to mock me, if ye really pity me, crush sensation and memory, let me become as nought, but if not, depart, depart, and leave me in darkness." Shelly 
uses apostrophe, because she tries to talking to stars, clouds, and winds which is a death object. But in her imagination, she talks with them. As a simply identification of defining apostrophe in literature, it is addresses a person who is dead or not present, or is an inanimate object that the speaker is addressing as if it were alive

\section{5) Alliteration}

Furhormore the contributor of the above site adds "Alliteration is derived from Latin"s "Latira". It means "letter of alphabet". It is a stylistic device in which a number of words, having the same first consonant sound, occur close together in a series". Abrams defined alliteration is the repetition of a speech sound in a sequence of nearby words. He adds " The term is usually applied only to consonants, and only when the recurrent sound begins a word or a stressed syllable within a word ". He also adds examples as follows "Consider the following examples, "But a better butter makes a batter better". In that sentence is alliterative because the same first letter of words (B) occurs close together and produces alliteration in the sentence ". The use of alliteration it does not depend on letters but on sounds. It creates a musical effect in the text that enhance the pleasure of reading a literary piece. In fact, alliteration makes a literary works more interesting and easier to remember.

\section{6) Allusion}

Abrams states " a passing reference, without explicit identification, to literary or historical person, place, or event, or to anohter literary work or passage is called allusion ", and "Most allusion serve the illustrate or expand upon or enhance a subject, but some are used in order to undercut it ironycally by the discrepancy between the subject and the allusion ". "For instance, you make a literary allusion the moment you say, "I do not approve of this quixotic idea." Quixotic means stupid and impractical derivedfrom Cervantes"s "Don Quixote", a story of a foolish knight and his misadventures ". The use of allusions enables writers or poets to simplify complex ideas and emotions. The use of allusion also can help the reader to describe their ideas and emotions more dramatics in daily and literary works. 


\section{7) Overstatement (Hyperbole)}

Abrams says "The figure of speech, or trope, called hyperbole is bold overstatement, or the extravagant exaggeration of fact or of possibility ". In addition, Hyperbole derived from a Greek word meaning "over-casting", is a figure of speech that involves an exaggeration of ideas for sake of emphasis". For both meaning of hyperbole, the writer makes it simply that hyperbole is an exaggeration which is to emphasis an idea. Abrams adds" An example of hyperbole is given by $\mathrm{C}$. Colloid in his novel entitled The Adventures of Pinocchio, "He cried all night, and dawn found him still there, though his tears had dried and only hard, dry sobs shook his wooden frame. But these were so loud that they could be heard by the faraway hills ...". Collodi emphasis all night to exaggeration the crying of Pinocchio until his tears became dry. By using hyperbole, a writer or a poet makes common human feelings remarkable and intense to such an extent that they do not remain ordinary.In fact, hyperbole is used for the writer to catch the reader"s attention.

\section{8) Understatement (Litotes)}

"Litotes, derived from a Greek word meaning "simple", is a figure of speech which employs an understatement by using double negatives or, in other words, positive statement is expressed by negating its opposite expressions, " (https:// literarydevices.net/litotes/) ". According to Abrams, " understatement represent something as very much less in magnitude or importance than really is, or is ordinarily considered to be ". "Saying, "She is not a beauty queen", means "She is ugly". " The example shows a negative statement by negating the positive expression. Litotes uses ironical understatement in order to emphasize an idea or situation rather than minimizing its importance ".

\section{9) Irony}

Abrams defines Irony as follows "Irony is a statement in which the meaning that a speaker implies differs sharply from the meaning that is ostensibly expressed "." It may also be a situation that ends up in quite a different way than what is generally anticipated ( https://literarydevices.net/irony/)". Irony have a three most common uses, they are: (1) verbal irony is when a speaker says 
one thing but means another. For example, in Romeo and Juliet by Shakespeare.

"Act I Scene V, " Go ask his name: if he be married. My grave is like to be my wedding bed." In this scene, Juliet commands her nurse to find out who Romeo was, and says if he were married, then her wedding bed would be her grave. The audience think and knows that she is going to die on her wedding bed (https://literarydevices. net/irony/)". (2) situational irony is when something happens and reversal of expectations occurs. For example, in Harry Potter by J.K Rowling, Harry Potter series is one of the most popular novels having employed situational irony. Until seven novels, the audience believes that Harry can kill Voldemort, the evil lord. However, the audience is thrown off guard near the end of this series when it becomes clear that Harry must allow evil lord to kill him, so that Voldemort"s soul could become mortal once again. Hence, Harry allows himself to be killed in order to defeat Voldemort, which is exactly the opposite of the audience"s expectations. By using situational irony, Rowling has actually done a great job of adding a twist to the story to create a complex conflict (https://literarydevices. net/irony/)". (3) dramatic irony is frequently employed by writers in literary works. In dramatic irony, the characters are oblivious of the situation, but the audience is not. For example, in dramatic comedy movie, There"s Something About Mary by Jonathan Richman"s, "I"ve done it several times before" and "it"s no big deal," generate laughter." This looks quite funny due to this misunderstanding when Ted thinks that the police have arrested him for picking up hitchhiker, the audience knows that the police interogate him about a murder ( https://literarydevices.net/irony/)".

"In simple words, it is a difference between appearance and reality. Ironical statements and situations in literature develop reader"s interest. Irony makes a work of literature more powerful meaning, and force the readers to use their imaginations to comprehend the underlying meanings of the text. Moreover, real life is full of ironical expressions and situations. Therefore, the use of irony brings a work of literature to the life ( https://literarydevices.net/irony/)".

\section{0) Paradox}

"The term Paradox is from the Greek word "paradoxon" that mean contrary 
to expectations, existing belief or perceived opinion " (https://literarydevices.net/paradox). Abrams also defines " a paradox is a statement which seems on its face to be logically contradictory or absurd, yet turns out to be interpretable in a way that makes good sense. "In literature, paradox is not just a clever or comical statement or use of words" https://literarydevices.net/paradox. In play of Shakespeare, Hamlet says, "I must be cruel to be kind." This announcement does not seem to make sense. Hamlet is talking about his mother, and how he intends to kill Claudius to avenge his father"s death. This act of Hamlet will be a tragedy for his mother who is married to Claudius. Hamlet does not want his mother to be the beloved of his father"s murderer any longer, and so he thinks that the murder will be good for his mother " https://literarydevices.net/paradox). Some types of paradox in poetry are meant to communicate a tone of irony to its readers as well as lead their thoughts to the immadiate subject. "Paradox create feelings of intrigue and interest in reader"s minds to make them think deeper and harder to enjoy the real message of the poem" https://literarydevices.net/paradox).

\section{1) Metonymy}

"Metonymy is a figure of speech in which in author uses a word (or words) for another word (or words) based upon either a sequential, spatial, temporal, or attributive association between the two "https://www.sil.org/.../Metonymyand Synecdochein theNewTest....). "For example, the word "kettle" is quite distinct in meaning from "water". The meaning of the word "kettle" has been extended so that it is substitutable for "water", even though this extended meaning is restricted in distribution to this one syntactic combination "https://www.sil.org/.../ Metonymyand SynecdocheintheNewTest). " Another example, the word "crown" which means power or authority is a metonymy. Both of metonymy between synecdoche resemble each other but are not the same. Synecdoche refers to a thing by the name of one of its parts and metonymy, the word we use to describe another thing is closely linked to that particular thing, but is not a part of it " (from https://literarydevices.net/metonymy/).Saying, "Let me give you a hand", it is 
describe the hand closely linked to help other people. It means giving a hand is giving a help for other person. Furthermore, metonymy, like other literary devices, is employed to add a poetic color to words to make them come to life. The writer makes it simple, metonymy is literary works that describe in a creative way to give more profound meaning from ideas and objects.

\section{2) Synecdoche}

John Beekman defines Synecdoche as follows" Synechdoche, like metonymy, is based upon association. It is defined as a figure of speech by which the whole of a thing is put for a part, or a part for the whole ". The word "boots" usually refers to soldiers. Because boots is a part of whole soldiers and it is became identic things. " Another example is given by Frank R. Stockton in The Lady or the Tiger? , "His eye met hers as she sat there paler and white than anyone in the vast ocean of anxious faces about her." Faces is refers to people (not just their faces). Faces means is a whole part body of people " ( https://literarydevices.net/metonymy/). Abrams assumes that "By using synecdoche, the writers give some common ideas and objects deeper meaning and thus draw reader"s attention and describe simple ordinary things creatively with the aid of this literary device ".

\section{3) Onomatopoeia}

Abrams states " The other part of figurative language is Onomatopoeia. It is sometimes called echoism. It is used both in a narrow and in a broad sense ". Abrams adds "Onomatopoeia designates a word, or a combination of words, whose sound seems to resemble closely the sound it denotes: "hiss", "buzz", "rattle", "bang". The perceived similarity is due as much to the meaning, and to the feel of articulating the words, as to their sounds". "Onomatopoeia also defined as a word, which imitates the natural sounds of a thing ". "For instance, saying, "whisper" is not only represents the sound of people talking quietly, but also describes the action of people talking quietly". "An example onomatopoeia is given by Lerner and Loewe in Get Me to the Church on Time, "I"m getting married in the morning!, Ding dong! The bells whole " ." The word "boots" usually refers to soldiers. Because boots is a part of whole soldiers and it is became identic things. Another example is given by Frank R. Stockton in 
The Lady or the Tiger? , "His eye met hers as she sat there paler and white than anyone in the vast ocean of anxious faces about her." Faces is refers to people (not just their faces). "Faces means is a whole part body of people " . " By using synecdoche, the writers give some common ideas and objects deeper meaning and thus draw reader"s attention and describe simple ordinary things creatively with the aid of this literary device (https://literary devices.net/metonymy/).

\section{4) Onomatopoeia}

Abram says " The other part of figurative language is Onomatopoeia. It is sometimes called echoism. It is used both in a narrow and in a broad sense ". He adds " Onomatopoeia designates a word, or a combination of words, whose sound seems to resemble closely the sound it denotes: "hiss", "buzz", "rattle", "bang". The perceived similarity is due as much to the meaning, and to the feel of articulating the words, as to their sounds ". " Onomatopoeia also defined as a word, which imitates the natural sounds of a thing " ( https://literarydevices.net/ metonymy//)". "For instance, saying, "whisper" is not only represents the sound of people talking quietly, but also describes the action of people talking quietly " ( https://literarydevices.net/metonymy/). An example onomatopoeia is given by Lerner and Loewe in Get Me to the Church on Time, "I"m getting married in the morning!, Ding dong! The bells are gonna chime." The word "ding dong" is the sound of bells ringing. In addition, it makes the description livelier and interesting, appealing directly to the senses of the reader. It can be concluded that onomatopoeia is literary works to create emphasis of the sound effect. On the other hand, onomatopoeia helps the reader to hear the sounds the words they reflect. The writer makes the reader"s feeling to enthusiastic to hear it and exciting to imitate the sound.

\section{Methodology}

In analyzing figurative language of Avril Lavigne songs lyrics in album Avril Lavigne, the writers focuses on figurative language using qualitative research methodology. The data for this analysis are taken from several books, and 
internet as well as the lyrics. And to increase resources about the research the writer goes over listening to the music, analaysing the lyric, and grouping into figurative language.

\section{B. RESULT AND DISCUSSION}

This part is a process analyzing from data taken. The writers take data from type Avril Lavigne songs in Album Avril Lavigne. The process is divided into three parts. First the lyric of Avril Lavigne songs in Album Avril Lavigne, second type of figurative Language, and the third is the meaning of Figurative Language. Here are the slected song of Avril. The writers have already analyzed some lyric songs, but now the writers will only take one lyric song with title "Here to Never Growing Up" as example. While other lyric songs summarized in the result of the research.

\section{a. Here's to Never Growing Up}

Table B.1 : List of Figurative Language Used in Here's to Never Growing Up

\begin{tabular}{|c|c|c|c|}
\hline & The Lyric & Figurative Language & Explanation \\
\hline 1 & $\begin{array}{l}\text { Singing Radiohead at the top } \\
\text { of our lungs, With the boom } \\
\text { box blarin' as we're fallin' in } \\
\text { Love }\end{array}$ & Metaphor & $\begin{array}{l}\text { Comparing between } \\
\text { Radiohead and Avril } \\
\text { Lavigne. Radiohead } \\
\text { is one of the famous } \\
\text { band in the world } \\
\text { who had been } \\
\text { inspired to using } \\
\text { subject youth } \\
\text { rebellion with the same } \\
\text { themed of } \\
\text { Avril's video clip. It } \\
\text { means, when you } \\
\text { sing a song of Avril }\end{array}$ \\
\hline
\end{tabular}




\begin{tabular}{|c|c|c|c|}
\hline & The Lyric & Figurative Language & Explanation \\
\hline & & & $\begin{array}{l}\text { you should be singing } \\
\text { out loud like you } \\
\text { sing a song of } \\
\text { Radiohead band. }\end{array}$ \\
\hline 2 & $\begin{array}{l}\text { I'm like yeah whatever, we're } \\
\text { still living like that }\end{array}$ & Simile & $\begin{array}{l}\text { Comparing two } \\
\text { different object, yeah } \\
\text { whatever and still } \\
\text { living like that } \\
\text { through connector } \\
\text { like which have } \\
\text { things in common. } \\
\text { Whatever you are } \\
\text { doing is still the } \\
\text { same and you living } \\
\text { the same rule and } \\
\text { also never change } \\
\text { anything. }\end{array}$ \\
\hline 3 & $\begin{array}{l}\text { I don't think we'll ever } \\
\text { Change }\end{array}$ & Litotes & $\begin{array}{l}\text { Positive statement is } \\
\text { expressed by } \\
\text { negating its positive } \\
\text { expression. Instead } \\
\text { of saying being } \\
\text { young, she preferred } \\
\text { I don't think we'll } \\
\text { ever change. }\end{array}$ \\
\hline 4 & $\begin{array}{l}\text { We don't ever stop, and we're } \\
\text { never gonna change }\end{array}$ & Litotes & $\begin{array}{l}\text { Posotive statement is } \\
\text { expressed by } \\
\text { negating its positive } \\
\text { expression. We don't } \\
\text { ever stop, and we're } \\
\text { never gonna change } \\
\text { is negative } \\
\text { expression which } \\
\text { from the positive } \\
\text { statement we can } \\
\text { stop, and we're ever }\end{array}$ \\
\hline
\end{tabular}




\begin{tabular}{|c|l|l|l|}
\hline \multicolumn{1}{|c|}{ The Lyric } & Figurative Language & \multicolumn{1}{c|}{ Explanation } \\
\hline 5 & $\begin{array}{l}\text { Oh whoa, oh whoa, here's to } \\
\text { never growing up } \\
\text { Oh whoa, oh whoa, here's to } \\
\text { never growing up }\end{array}$ & Alliteration & $\begin{array}{l}\text { Giving the same } \\
\text { sound / o / and / w / } \\
\text {. Repeating the } \\
\text { sound on the chorus. }\end{array}$ \\
\hline 6 & $\begin{array}{l}\text { We live like rock stars, dance } \\
\text { on every bar }\end{array}$ & Simile & $\begin{array}{l}\text { Comparing two } \\
\text { different object, we } \\
\text { and rock star } \\
\text { through connector } \\
\text { like which have } \\
\text { things in common. } \\
\text { Avril Lavigne as a } \\
\text { rock star and we can } \\
\text { living like her with a } \\
\text { rock style. }\end{array}$ \\
\hline
\end{tabular}

There are four types of figurative language that the writer found in this song. They are : Metaphor, Simile, Litotes, Alliteration. Other lyrics are : Bitchin' Summer, Give You What You Like, Hello Kitty, Sippin' On Sunshine.

Based on the table of list of al figurative languages from table, the writers classified some kinds of figurative language that found in selected songs into a table and including for the amount precentage of each of them. Referring to the table above, its figurative language are summarized in the following table. The other tables of figurarive languages attached in appendix

Table B.2 The Percentage Use of Figurative Language

\begin{tabular}{|c|l|c|c|}
\hline No & \multicolumn{1}{|c|}{ Figurative Language } & Total & Percentage \\
\hline 1 & Metaphor & 1 & $3.6 \%$ \\
2 & Simile & 7 & $25 \%$ \\
3 & Personification & 6 & $21.4 \%$ \\
4 & Hyperbole & 5 & $17.8 \%$ \\
5 & Litotes & 2 & $7.14 \%$ \\
\hline
\end{tabular}




\begin{tabular}{|c|l|c|c|}
6 & Alliteration & 5 & $17.8 \%$ \\
7 & Allusion & 1 & $3.6 \%$ \\
8 & Apostrophe & 0 & $0 \%$ \\
9 & Irony & 0 & $0 \%$ \\
10 & Metonymy & 0 & $0 \%$ \\
11 & Onomatopoiea & 1 & $3.6 \%$ \\
12 & Paradox & 0 & $0 \%$ \\
13 & Synecdoche & 0 & $0 \%$ \\
\hline \multicolumn{2}{r|}{ Total } & 28 & $100 \%$ \\
\hline
\end{tabular}

\section{CONCLUSION}

The last is about what figurative language widely used in Avril Lavigne songs. It can be seen from the table of percentage above, it is simile with the total use is Or $25 \%$. It can be conclude that the singer of the songs comparing two different objects to describe the songs are relate the feelings into personal experiences. In addition, it also can be categorized that simile belongs to the easiest figurative language to use in Avril Lavigne songs.

After that, what figurative language used least in Avril Lavigne songs. The percentage shows are metaphor, allusion, and onomatopeia only one times or $3.6 \%$. The singer used those figurative language very minimally in her songs. Then, for apostrophe, irony, metonymy, paradox, and synecdoche is not even up to one percent. The singer may prefer, compare two different things which have similarities and the use of a connector, to play on the song lyric. Therefore, she only adding some the least figurative language for making the song more interesting .According to the above discussion, researchers would like to briefly conclude that the songs dominant of simile as the most widely used in her songs.

The total use of it is 7 or $25 \%$. On the other hand, she has used metaphor, allusion and onomatopoeia with very few. Only one examples of those did the researcher find in this songs with the percentage is $3.6 \%$. 


\section{BIBLIOGRAPHY}

Abrams, M.H. 1999. A Glossary of Literary Terms. United States of America : Earl McPeek.

Fadaee, Elaheh. 2011. Symbols, metaphors and similes in literature: A case study of "Animal Farm". Journal of English and Literature, Volume 2(2), pp. 19-27

Giora, Rachel. (1997). Understanding figurative and literal language: The graded salience hypothesis. Retrieved July 27, 2017, from: http://www.tau.ac.il / giorar/files/Giora 997 Graded salience hypothesis.pdf

Grocke, Denise \& Wigram,Tony. (2007). Receptive Methods in Music Therapy, Retrieved July 27, 2017, from: http: //my.ilstu.edu/ crropp /Documents /PDF\% 20files\% 20341/Grocke

Hussain, Rashid. "Metaphor and similes in Literature". International Journal of Humanities and Social Science Invention. 2014, Volume 3 Issue 9, September. Pp. 01-02

Kothari, C. R.2004.Research Methodology:Methods \& Techniques. New Delhi: New Age International

Kövecses,Zoltán. 2003. Language, Figurative Thought, and Cross -

Cultural Comparison. Lawrence Erlbaum Assosiates, Inc.,

Lakoff, George \& Johnson,Mark. 1980. Conceptual Metaphor in Everyday Language. The Journal of Philosophy, Volume 77

Murphey, Tim Ph.D. (1993, May). The Hypnotic Open Text of Pop Songs, Oxford University Press,

New, Christopher. 2001. Philosophy of Literature:an introduction. New York:

Routledge Taylor and Francis Group

Ortony, Andrew. 1980. Understanding Metaphors. Cambridge, Massachusetts: Bolt Beranek and Newman Inc. 
Robson, Mark \& Stockwell, Peter. 2005. Language in Theory. New York: Routledge Taylor and Francis Group.

Tomal, Daniel R.2003.Action Research for Educators.Oxford:The Scarecrow Press, Inc. 